\title{
ON EULER HARMONIC IDENTITIES FOR MEASURES AND ERROR ESTIMATIONS
}

\author{
AMBROZ ČIVLJAK
}

Abstract. Some new approximations of functions are given by using generalized Euler identities involving real Borel measures and harmonic sequences of functions. Also, we estimate those approximations for different classes of functions and different types of measures.

Mathematics subject classification (2010): Primary 41A30, Secondary 46E15, 28A25, 26A16, 26A45, 26A46, 26D15.

Keywords and phrases: Borel measures, harmonic sequences of functions, generalized Euler identities, L-Lipschitzian function, continuous functions of bounded variation.

\section{REFERENCES}

[1] A. Aglić Aljinović, Lu. Dedić, M. Matić And J. PeČarić, On weighted Euler harmonic identities with applications, Math. Inequal. Appl., 8 (2), (2005), 237-257.

[2] G. A. Anastassiou, Advanced Inequalities, Series on Concrete and Applicable Mathematics, vol. 11, World Scientific Publishing Co. Pte. Ltd.

[3] A. ČIVlJAK And LJ. Dedić, Generalizations of Ostrowski inequality via biparametric Euler harmonic identities for measures, Banach J. Math. Anal. 4 (1), (2010), 170-184.

[4] A. ČIVLJAK, LJ. Dedić And M. Matić, Euler harmonic identities and moments of real Borel measures, Math. Inequal. Appl., 12 (4), (2009), 733-743.

[5] A. ČIVLJAK, LJ. DEDiĆ AND M. MATiĆ, Euler-Grüss type inequalities involving measures, Internat. Ser. Numer. Math., 157, (2008), 109-120, Birkhäuser, Basel.

[6] A. Čivljak, Lj. Dedić And M. Matić, On an integration-by-parts formula for measures, J. Inequal. Pure Appl. Math., 8 (2007), no. 4, Article 93, 13 pp.

[7] A. ČIVlJak, Lu. Dedić And M. Matić, On Ostrowski and Euler-Grüss type inequalities involving measures, J. Math. Inequal., 1 (1), (2007), 65-81.

[8] LJ. DEDiĆ, M. MATIĆ AND J. PEČARIĆ, On Euler mid-point formulae, ANZIAM Journal, 46, (2005), 417-438.

[9] Lu. Dedić, M. Matić And J. PeČArić, On Euler trapezoid formulae, Appl. Math. Comp. 123 (2001) 37-62.

[10] Lj. Dedić, M. MATiĆ AND J. PEČARIĆ, On generalizations of Ostrowski inequality via some Eulertype identities, Math. Inequal. Appl., 3 (3), (2000), 337-353.

[11] Lj. Dedić, M. Matić, J. PeČARić And A. Vukelić, On generalizations of Ostrowski inequality via Euler harmonic identities, J. Inequal. Appl., 7 (6), (2002), 787-805.

[12] S. S. Dragomir And N. S. BARnett, An Ostrowski type inequality for mappings whose second serivatives are bounded and applications, J. Indian Math. Soc (S. S.), 66 (1-4) (1999), 237-245.

[13] I. Franjić, J. PEČArić, I. PERIĆ AND A. Vukelić, Euler integral identity, quadrature formulae and error estimations, Monographs in inequalities 2, Element, Zagreb, 2011.

[14] V. I. KRYLOV, Approximate calculations of integrals, Macmillan, New York-London, 1962.

[15] A. OstrowsKI, Über die Absolutabweichung einer differentiebaren Funktion von ihrem Integralmittelwert, Comment. Math. Helv., 10 (1938), 226-227. 